\title{
The Political Economy of Recent Economic Growth in India
}

\author{
Raghbendra Jha
}

\begin{abstract}
The political economy of India's economic growth is an issue of abiding interest. Higher and sustained economic growth has, all over the world, been the surest and most time tested means of raising living standards and reducing poverty. Further, given that it is a functioning democracy, economic policy in India can often be dictated by political expediency as political parties indulge in competitive populism in the face of improvements in social indicators such as literacy, infant mortality and the like lagging behind rises in the rate of economic growth. Thus the political economy of policy formulation is an important area of concern. Finally, an analysis of what policies can be undertaken given these constraints is an important indicator of potential welfare implications of policies for such a large section of humanity.

Several recent reviews of India's recent growth experience exist (Rodrik and Subrahmanian, 2004, Kelkar, 2004, and Thirlwell, 2004 are three examples). The value added of the present paper is to place India's growth experience within a broader political economy perspective. It documents the broad contours of economic growth in India; it then analyzes some emerging obstacles to higher economic growth and finally the prospects for accelerating the economic reforms program to place India on a sustained higher economic growth path.
\end{abstract}

All correspondence to:

Prof. Raghbendra Jha, Australia South Asia Research Centre, Research School of Pacific and Asian Studies, Australian National University, Canberra, ACT 0200, Australia

Fax: + 61261250443

Email: r.jha@anu.edu.au 


\section{Introduction}

The political economy of India's economic growth is an issue of abiding interest. Higher and sustained economic growth has, all over the world, been the surest and most time tested means of raising living standards and reducing poverty. Further, given that it is a functioning democracy, economic policy in India can often be dictated by political expediency as political parties indulge in competitive populism in the face of improvements in social indicators such as literacy, infant mortality and the like lagging behind rises in the rate of economic growth. Thus the political economy of policy formulation is an important area of concern. Finally, an analysis of what policies can be undertaken given these constraints is an important indicator of potential welfare implications of policies for such a large section of humanity.

Several recent reviews of India's recent growth experience exist (Rodrik and Subrahmanian, 2004, Kelkar, 2004, and Thirlwell, 2004 are three examples). The value added of the present paper is to place India's growth experience within a broader political economy perspective. It documents the broad contours of economic growth in India (section II); then analyzes the emerging obstacles to higher economic growth (section III) and finally the prospects for accelerating the economic reforms program to place India on a sustained higher economic growth path (section IV). Section V concludes.

\section{The Record of Economic Growth in India}

The record of economic growth (annual rate of growth of real GNP) in independent India has been uneven. Until about 1980 growth rates were low and subject to considerable volatility. This record has improved since then. In Table 1 we depict salient characteristics of aggregate economic growth in India.

Table 1: Some Basic Characteristics of Growth of Real GNP in India

\begin{tabular}{|l|c|c|}
\hline \multicolumn{1}{|c|}{ Period } & $\begin{array}{c}\text { Mean Annual Growth Rate } \\
\text { (percentages) }\end{array}$ & $\begin{array}{c}\text { Standard Deviation of Year to Year Growth Rate } \\
\text { (percentages) }\end{array}$ \\
\hline $1951-52$ to $1959-60$ & 3.58 & 2.62 \\
\hline $1960-61$ to $1969-70$ & 3.91 & 3.64 \\
\hline $1970-71$ to $1979-80$ & 3.05 & 4.16 \\
\hline $1980-81$ to $1989-90$ & 5.65 & 2.27 \\
\hline $1990-91$ to $1999-00$ & 5.83 & 1.97 \\
\hline $1992-93$ to $1999-00$ & 6.46 & 1.16 \\
\hline
\end{tabular}

Source: Author's calculation based on data from Reserve Bank of India Handbook of Statistics on the Indian Economy 
In aggregate terms growth appears to have picked up significantly since the 1980s. Further, the variability of this growth (as measured by the standard deviation) has come down significantly. Per capita GDP growth which was 1.2 percent per annum during 1972-82, accelerated to 3.0 percent during 1982-92 and further to 3.9 percent during 1992-2002. So the Indian economy has been enjoying high and relatively stable rates of growth for almost a quarter century now. ${ }^{1}$

However, although India's economic growth record has been truly impressive the country does not perform as well on a broader set of human development indicators. India's Human Development Indicator (HDI) score, for example, improved only marginally from 0.302 in 1981 to 0.381 in 1991 and 0.472 in 2001. India’s HDI rank in 2002 was $124^{\text {th }}-$ which was a deterioration on the rank (of $115^{\text {th }}$ ) attained in the previous year. In 2003 there was further slippage and India was $127^{\text {th }}$ in the global ranking.

Assessment of performance according to a broader criteria such as human development indicators is important for at least two reasons - first, these figures indicate whether economic growth, as such, has been impacting upon the poor. Second, the poor progress in areas other than GDP (but which are of considerable significance to the population at large) might risk loss of popular support for the policies that made high GDP growth possible in the first place. This, as argued later in the chapter, might then appear as a constraint on attaining high growth rates.

What is the sectoral distribution of India's economic growth? Table 2 displays broad averages of sectoral growth rates as well as the significance of these sectors measured by their shares in GDP. Agricultural growth has continued to fluctuate considerably even as the share of agriculture in GDP has come down sharply. ${ }^{2}$ Manufacturing sector growth rates have not been particularly high and the share of industry in GDP has been stagnant at about 22 per cent. Manufacturing growth was high in the initial years of the post reforms period but fell sharply in 2001-02. The subsequent pick-up in 2002-03 was probably because of the

\footnotetext{
${ }^{1}$ Latest available data (RBI 2004) indicates that there has been a further sharp acceleration in the growth rate of real GDP in the second quarter of 2003-04. In the third quarter this reached doubledigit levels. All sectors grew sharply. Agriculture recovered smartly from a downturn in 2002-03 on the back of two successive good harvests. The manufacturing and services sector continued their rapid growth. It remains to be season whether this sharp rise is a temporary blip in the growth trend.

${ }^{2}$ The share of agriculture in employment is, however, much higher. One of the current important anomalies in the Indian economy is that a sector that produces 25 percent of GDP employs 65 precent of the labour force.
} 
lower base in 2001-02. Similar comments hold for mining. Growth in electricity production has been slow - perhaps reflecting the poor state of electricity generation and, particularly, transmission and distribution in India. The highest growth sector has been services. Growth in this sector has occurred across a broad range and has been the most stable of all sectoral growth rates. As a consequence, the share of services in GDP has gone up substantially.

Table 2: Growth Rates of Real GDP (Per cent)

\begin{tabular}{|c|c|c|c|}
\hline Sector & $2002-03$ & 2001-02 & $\begin{array}{c}1992-93 \\
\text { to } 2001 \text { average }\end{array}$ \\
\hline Agriculture and Allied Activities & $\begin{array}{c}-3.2 \\
(22.1)\end{array}$ & $\begin{array}{c}5.7 \\
(23.9)\end{array}$ & $\begin{array}{c}3.0 \\
(27.9)\end{array}$ \\
\hline Industry, of which & $\begin{array}{c}5.7 \\
(21.8) \\
\end{array}$ & $\begin{array}{c}3.2 \\
(21.5) \\
\end{array}$ & $\begin{array}{c}6.6 \\
(22.0) \\
\end{array}$ \\
\hline (i) manufacturing & 6.1 & 3.4 & 7.2 \\
\hline (ii) mining and quarrying & 5.0 & 1.0 & 4.1 \\
\hline (iii) Electricity, gas and water supply & 3.9 & 4.3 & 5.9 \\
\hline Services, of which & $\begin{array}{c}7.1 \\
(56.1)\end{array}$ & $\begin{array}{c}6.5 \\
(54.6)\end{array}$ & $\begin{array}{c}7.7 \\
(50.1)\end{array}$ \\
\hline (i) Trade, hotels, restaurants, transport and communication & 7.8 & 8.7 & 8.3 \\
\hline (ii) Financing, insurance, real estate and business services & 6.1 & 4.5 & 8.1 \\
\hline (iii) Community, social and personal services & 6.8 & 5.6 & 7.3 \\
\hline (iv) Construction & 7.2 & 3.7 & 5.5 \\
\hline GDP at factor cost & 4.3 & 5.6 & 6.1 \\
\hline
\end{tabular}

The evolution over time of the sectoral composition of Indian GDP is portrayed in Figure 1. 
Figure 1: Sectoral Composition of India's GDP

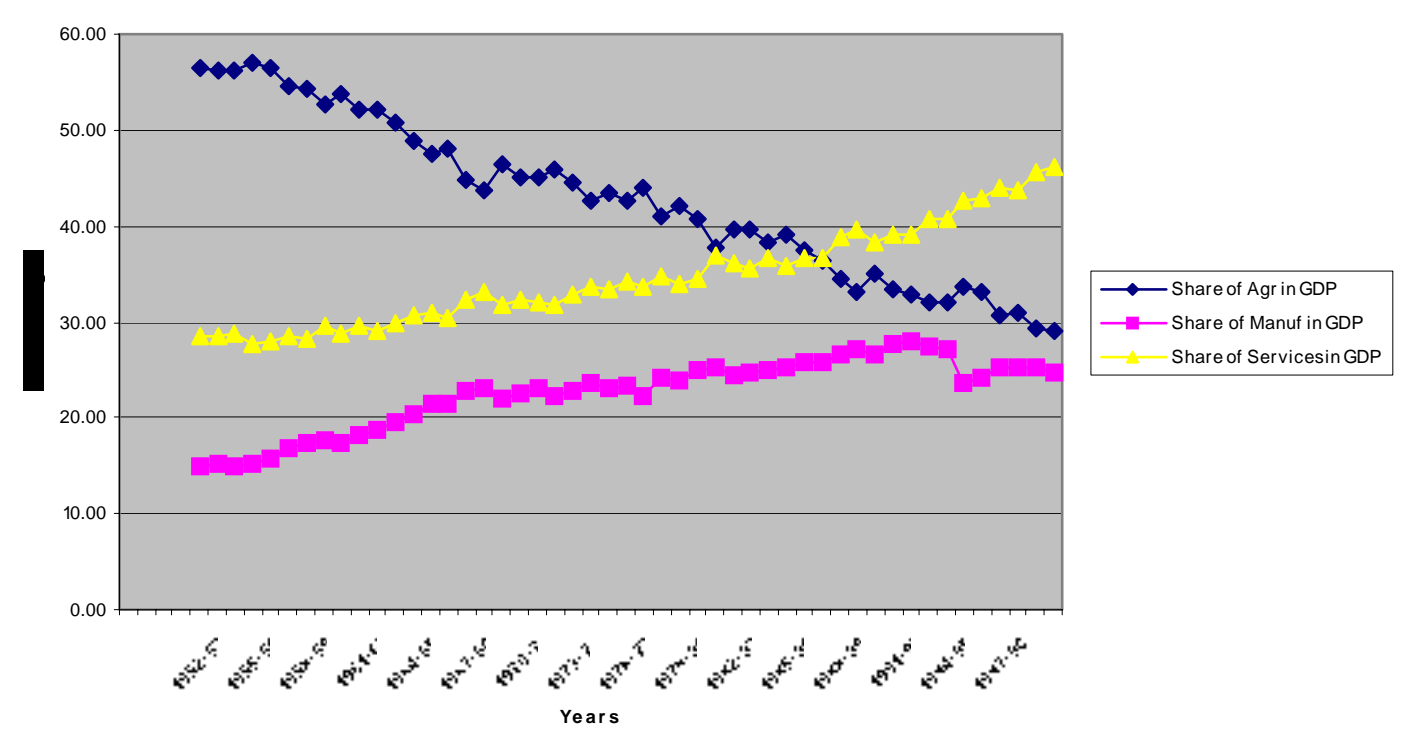

Source: Based on data from Handbook of Indian Statistics (2001), Reserve Bank of India.

The higher GDP growth rate beginning in the 1980s has been accompanied by an even sharper acceleration in total factor productivity growth. Rodrik and Subramanian (2004) examine a number of possible explanations for this rise in productivity/growth. Such explanations include Keynesian type demand-led expansion in the 1980s, the advent of the Green Revolution, and possible external and internal liberalization. However, they find empirical support for attitudinal changes in the governments of Indira and later, Rajiv Gandhi. These administrations, it is argued, began viewing private investment and enterprise more favorably. This had salutary effects on manufacturing sector productivity and later had substantial spillover effects. Such beneficial synergies were helped by the climate of deregulation and delicensing started in the early 1990s. Other authors have placed a much stronger emphasis on the role of the post 1991 reforms and downplayed the role of policy initiatives of the 1980s. ${ }^{3}$ To be sure, financial sector reforms began only in 1993 and are yet to be completed. ${ }^{4}$

\footnotetext{
${ }^{3}$ There has been a debate of sorts about whether attitudinal changes in the government bureaucracy or actual policy changes are better explanations for the acceleration in economic growth in India. In a country with an autarkic trade regime and a highly centralized administrative structure, attitudinal changes may well be the hardest to make. Hence, both policy measures as well as attitudinal changes should be regarded as essential as well as complementary explanations for this surge in the rate of growth.

${ }^{4}$ For a review of financial sector reforms in India see Sharma (2004).
} 
The current high rate of economic growth could well accelerate further as Kelkar (2004) has opined. Contributing to this acceleration is a broad series of reforms including financial sector reforms, increased globalization and widening and deepening of product and financial markets. The impact of such reforms gets reflected in key indicators such as market capitalization of the stock market, the technology and transparency of transactions, the sets of instruments traded, balance sheets of financial institutions and the degree of openness of the economy. At the same time a benign FDI policy framework has permitted greater tie-ups in high technology areas for production for domestic as well as external markets.

Adding to the impetus for higher economic growth are certain structural changes occurring in the Indian economy - particularly on the supply side. In 2000 the proportion of the Indian population in the working age group (15-64 age bracket) was 60.9\%. The UN's Population Division has projected that this ratio will surpass the proportion of Japanese in this age group by 2012 and climb to over $66 \%$ in 30 years. At that point in time it is poised to overtake China's population in the same age group. This is a very significant projection.

At the same time a quiet revolution is taking place in nutritional status in India. Table 3 (based on the author's computations) reports on the proportion of the rural population in India that is nutritionally deprived. This assessment is based on the assumption that all persons are working (alternately) according to three work norms - sedentary, moderate and heavy. These three norms imply different minimum calorific requirements with the "sedentary" norm being the lowest and the "heavy" norm being the highest. Results are reported for three time periods - 1987-88, 1993-94 and 1999-2000 for the rural sector where almost $70 \%$ of India's population (of 1,027,015,247 according to the 2001 census) resides. This table indicates the sharp decline in nutritional deprivation that has occurred in India. An even shaper decline has occurred in the severity of protein undernutrition in rural India. ${ }^{5}$ By all accounts, an at least comparable decline has occurred in the incidence of undernutrition and its severity in India's urban sector. Further, during the period 1991 to 2001 the literacy rate climbed from $51.54 \%$ to $65.38 \%$ in the aggregate, from $63.3 \%$ to $75.85 \%$ for males and from 38.79 to $54.16 \%$ for females, according to the figures of the 2001 Census of India.

\footnotetext{
${ }^{5}$ As explained in Jha (2001) the 1999-00 figures are not strictly comparable with those for earlier years. This was because of important sampling and other methodological changes in the $55^{\text {th }}$ Round of the National Sample Survey on which these results are based.
} 
Table 3 Calorie Deficiency in Rural India

\begin{tabular}{|c|c|c|c|}
\hline \multicolumn{4}{|c|}{ Sedentary Work Norm } \\
\hline & $1987-88$ & $1993-94$ & $1999-2000$ \\
\hline $\begin{array}{l}\text { Proportion of rural population } \\
\text { below minimum norm }\end{array}$ & 0.55 & 0.28 & 0.11 \\
\hline \multicolumn{4}{|c|}{ Moderate Work Norm } \\
\hline $\begin{array}{l}\text { Proportion of rural population } \\
\text { below minimum norm }\end{array}$ & 0.69 & 0.38 & 0.188 \\
\hline \multicolumn{4}{|c|}{ Heavy Work Norm } \\
\hline $\begin{array}{l}\text { Proportion of rural population } \\
\text { below minimum norm }\end{array}$ & 0.87 & 0.59 & 0.441 \\
\hline
\end{tabular}

Source: Author's calculations based on National Sample Survey Results for the $43^{\text {rd }}$ Round (1987-88), $50^{\text {th }}$ Round (1993-94) and $55^{\text {th }}$ Round (1999-00). "Sedentary" norm is defined as 2400 calories per day per adult male, 1900 per adult female and 1300 per child. "Moderate" norm is defined as 2800 calories per adult male, 2200 per adult female and 1300 per child. "Heavy" work norm is defined as 3900 per adult male, 3000 per adult female and 1300 per child.

Clearly India's labour force is undergoing rapid structural transformation: the proportion of the working population is rising; the labour force is less nutritionally deprived and increasingly literate. These changes imply substantial quality improvements in the Indian labour force. Economic theory and international experience leads us to believe that this will lead to sharp rises in labour productivity and an upward shift in the trend long run rate of growth of the Indian economy.

\section{Emerging Constraints on Rapid Economic Growth in India}

Having analyzed the prospects for rapid economic growth in India it behooves us to examine some emerging constraints. Evolution of the Indian economy according to the sanguine aggregate picture sketched above is subject to how these constraints to rapid economic growth in India work themselves out. We classify these constraints in four categories: (i) increasing spatial inequality; (ii) stagnating employment; (iii) high fiscal deficit; and (iv) inadequate growth of infrastructure. These constraints often reinforce each other particularly through the democratic political process. I now discuss these in turn. 


\section{i) Increasing regional inequality}

The aggregate economic growth narrative presented above masks substantial spatial variations. The regional variation in economic growth in India has remained stubbornly high despite the reforms. Table 4 presents mean growth rates and standard deviation for fifteen major states of India. In almost every year the mean growth rate has been lower than the (spatial) standard deviation of these growth rates, indicating persistently high spatial variability. As a consequence per capita incomes show a tendency to diverge across Indian states. Figure 2 plots the intertemporal behaviour of the coefficient of variation of per capita incomes across fifteen major Indian states. This shows an upward trend, further underscoring the divergence of incomes across space.

Table 4: Mean and Standard Deviation of Growth Rates of fifteen major Indian states

$\begin{array}{lcc} & \text { S.D.of growth of real SDP } & \text { Mean growth of real SDP } \\ 1981-82 & 6.57 & 6.18 \\ 1982-83 & 5.12 & 3.17 \\ 1983-84 & 5.95 & 5.93 \\ 1984-85 & 4.85 & 2.74 \\ 1985-86 & 6.03 & 5.62 \\ 1986-87 & 4.52 & 2.94 \\ 1987-88 & 7.68 & 3.83 \\ 1988-89 & 9.56 & 12.62 \\ 1989-90 & 5.07 & 5.56 \\ 1990-91 & 7.58 & 6.11 \\ 1991-92 & 6.41 & 3.16 \\ 1992-93 & 9.15 & 5.48 \\ 1993-94 & 4.30 & 5.98 \\ 1994-95 & 5.03 & 5.70 \\ 1995-96 & 4.41 & 5.27 \\ 1996-97 & 5.87 & 6.37 \\ 1997-98 & 4.15 & 4.38\end{array}$

Source: Author's calculations based on data in Handbook of Statistics on the Indian Economy, 2001, Reserve Bank of India.

This increasing divergence across the states gets reflected in other critical areas as well, e.g. the regional incidence of poverty, particularly rural poverty. Figure 3 shows that economic reforms have been accompanied by a rising coefficient of variation (across fifteen major Indian states) of the head count ratio of poverty. This coefficient of variation has had a distinct upward trend - particularly in the 1990s. 
Figure 2: CV of Real Per Capita Incomes in Fifteen Major Indian States

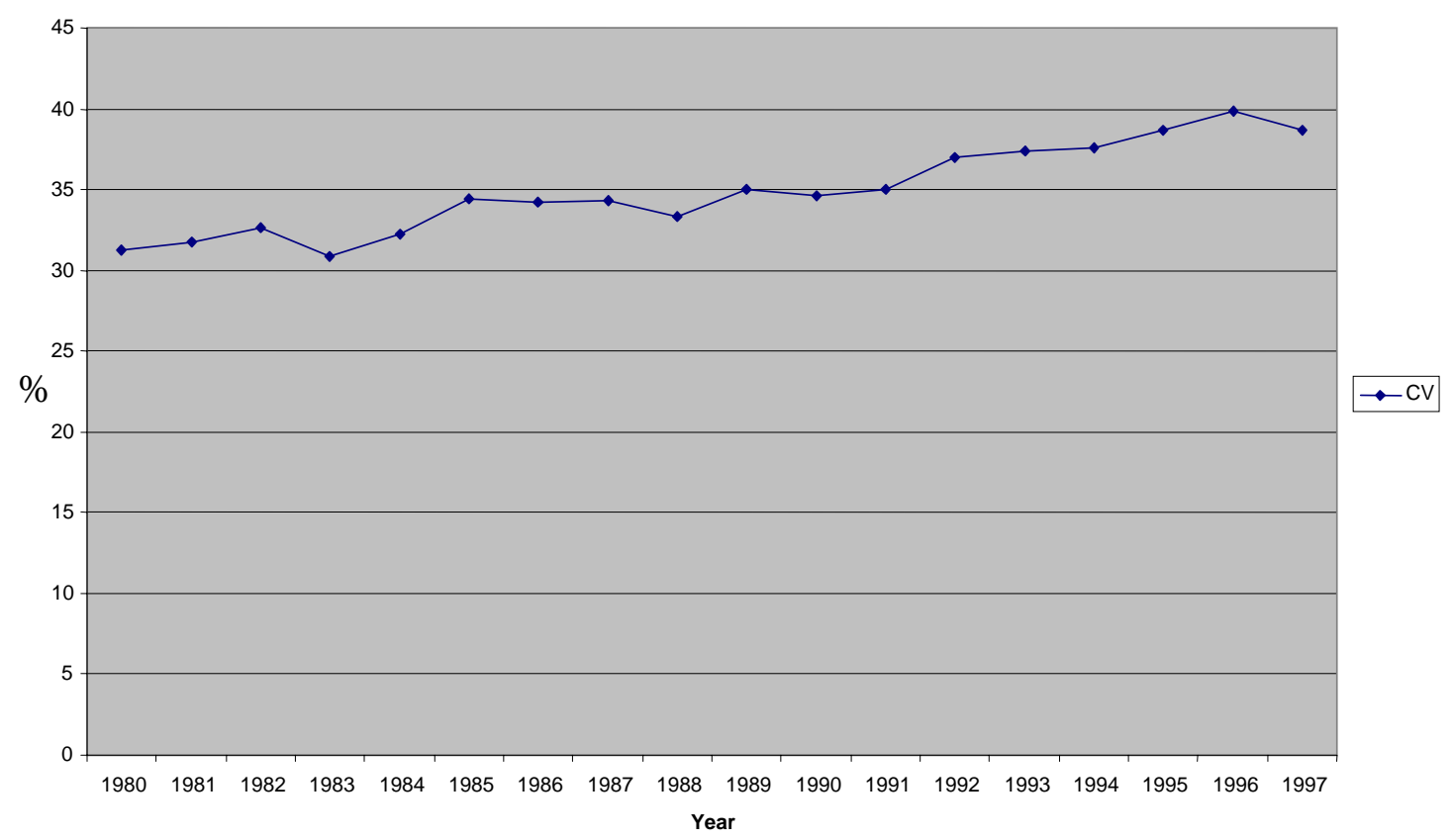

Source: Author's calculations based on data in Handbook of Statistics on the Indian Economy, 2001, Reserve Bank of India.

Figure 3: Coefficients of Variation of Head Count Ratios in the Rural, Urban and Aggregte Sectors

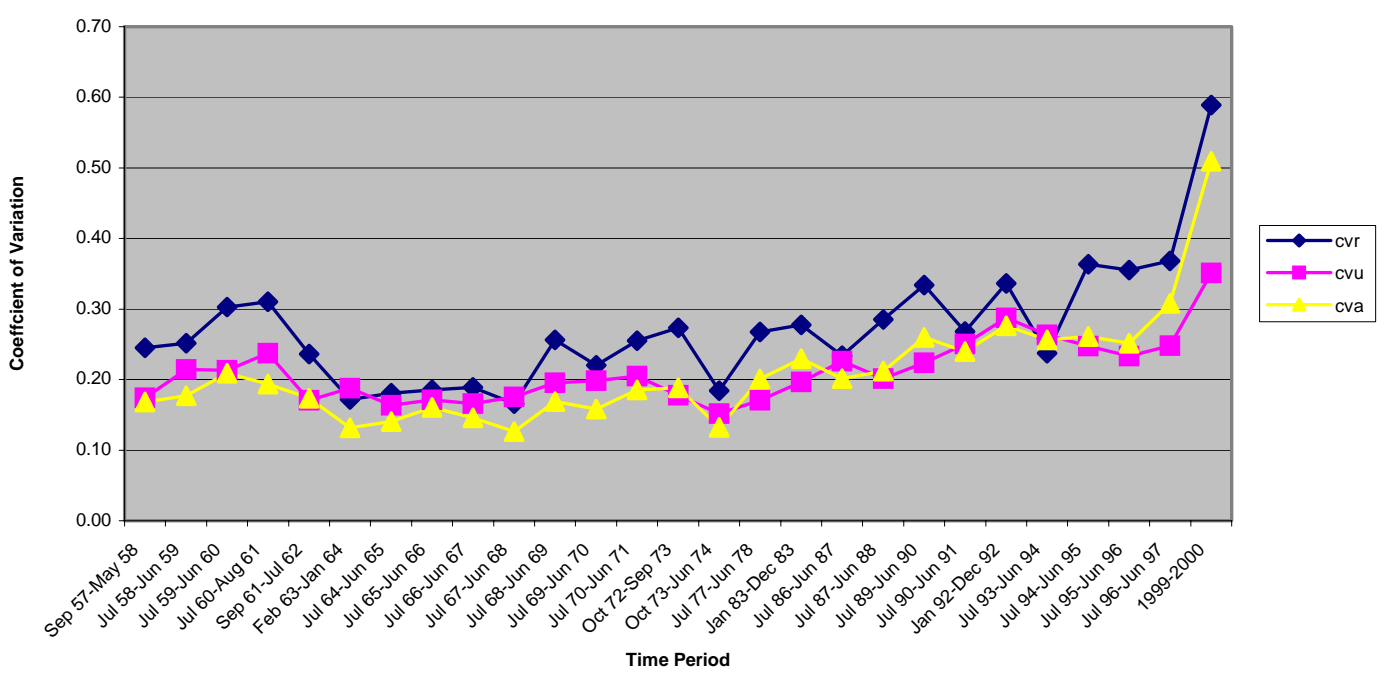

Note: $\quad \mathrm{cvr}=$ coefficient of variation of rural Head Count ratio, $\mathrm{cvu}=$ coefficient of variation of urban Head Count ratio; $\mathrm{cva}=$ coefficient of variation of aggregate Head Count ratio.

Source: Jha (2001) 
Jha (2001) shows that there is lack of convergence (in a formal statistical sense) in the incidence of rural poverty across Indian states both in terms of their ranks with respect to poverty as well as in terms of their levels of poverty. In fact in respect of the critical magnitudes of poverty, mean consumption and inequality of consumption, economic reforms do not seem to have made much difference to the inequality across Indian states for any category except urban mean consumption. This lack of convergence extends itself to the level of NSS agro-climatic zones (NSS regions) ${ }^{6}$ as Jha and Sharma (2003) point out.

This rising regional inequality is now a matter of concern. Reducing interstate disparities has been an important objective of government policy. The five-year plans of the Government of India have used public investment and industrial licensing to promote balanced regional development. Transfers from the central government to state governments under both the capital and the current categories through the Finance Commission and the Planning Commission are overwhelmingly equalizing in nature. Thus, the 10th Finance Commission (Government of India, 1994), the recommendations of which guided federal transfers between 1995-2000, advocated the following weight structure for the devolution formula: 20 percent on the basis of the population of 1971 and 60 percent on the basis of the inverse of the distance between the per capita income of the state in question from the mean per capita income. With the onset of market-oriented economic reforms, government transfers and investments began to play a diminished role $\mathrm{e}^{7}$ in the economic activity of states, so that regional disparities, which exist because of divergent economic conditions among the various states of India, get aggravated. Further, as Jha (2004) has shown, there has been some increase of personal inequality in India as a consequence of the economic reforms program.

To further investigate the increasing concentration of the poor in India I identify five states with the highest number of calorie-deprived and those with the highest number of expenditure poor in 1987-88 and follow the progress of these states over time. Data

\footnotetext{
${ }^{6}$ A National Sample Survey (NSS) region has a certain agro-climatic homogeneity within it. Small states such as Tripura constitute one region whereas larger states such as Uttar Pradesh are made up of more than one such region. States may not be a good unit of analysis in a regionally diversified country such as India. Even within the states there is considerable heterogeneity - coastal Maharashtra versus interior Maharashtra, Eastern vs. Western Madhya Pradesh etc. In the area of poverty incidence, for example, only Orissa and a few other states are such that there is a clear-cut congruence between high incidence of poverty and state geographical boundaries.

${ }^{7}$ It does not help that some of these poorest states have weak governance structures. In some cases funds are unspent because of inefficient administration, in other cases development funds are often diverted by cash-starved states to pay current administration salaries.
} 
pertaining to the rural sector from the last three quinquennial rounds of 1987-88 ( $43^{\text {rd }}$ round), $1993-94\left(50^{\text {th }}\right.$ round $)$ and $1999-2000$ ( $55^{\text {th }}$ round $)$ are used. All results refer to the rural sectors of these states and the national economy. Using norms developed by the Nutrition Expert Group of the National Institute of Nutrition for moderate work, the five states with largest number of people with nutritional intake below the recommended minimum in 198788 were UP (with 12.7 per cent of the calorie deprived in rural India), Bihar (with 9.7 per cent), MP (with 7.83 per cent), Maharashtra (with 7.03 per cent), and Tamilnadu (with 5.67 per cent). The performance of these five states over the three NSS rounds in respect of calorie deprivation is traced in the upper panel of Table 5. Also noted (within parentheses) are the shares of the rural sectors of these states in national rural population, reckoned according to the sizes of the NSS sample originating from these states: in 1987-88 UP had 12.81per cent of the national rural population.

\section{Table 5}

\begin{tabular}{|c|c|c|c|c|c|c|}
\hline \multirow[t]{2}{*}{ State } & \multicolumn{2}{|c|}{$43^{\text {rd }}$ round $(1987-88)$} & \multicolumn{2}{|c|}{$50^{\text {th }}$ round (1993-94) } & \multicolumn{2}{|c|}{$55^{\text {th }}$ round $(1999-2000)$} \\
\hline & $\begin{array}{l}\text { Per cent of } \\
\text { national total of } \\
\text { deprived } \\
\text { (Per cent of } \\
\text { national } \\
\text { population) }\end{array}$ & $\begin{array}{l}\text { Rank in terms of } \\
\text { number deprived } \\
1987-88\end{array}$ & $\begin{array}{l}\text { Per cent of } \\
\text { national total of } \\
\text { deprived } \\
\text { (Per cent of } \\
\text { national } \\
\text { population) }\end{array}$ & $\begin{array}{l}\text { Rank in terms of } \\
\text { number deprived } \\
1993-94\end{array}$ & $\begin{array}{l}\text { Per cent of } \\
\text { national total of } \\
\text { deprived } \\
\text { (Per cent of } \\
\text { national } \\
\text { population) }\end{array}$ & $\begin{array}{l}\text { Rank in terms of } \\
\text { number deprived } \\
1999-2000\end{array}$ \\
\hline \multicolumn{7}{|l|}{ Calories } \\
\hline$\overline{\mathrm{UP}}$ & $12.7(12.81)$ & 1 & $10.6(13.1)$ & 2 & $11.2(13.4)$ & 2 \\
\hline Bihar & $9.7(9.63)$ & 2 & $9.04(10.1)$ & 3 & $20.62(10.5)$ & 1 \\
\hline MP & $7.6(7.83)$ & 3 & $8.67(7.83)$ & 4 & $8.29 \quad(7.4)$ & 6 \\
\hline Maharashtra & $7.4(7.03)$ & 4 & $11 \quad(6.5)$ & 1 & $\begin{array}{ll}5.53 & (5.9) \\
\end{array}$ & 7 \\
\hline Tamilnadu & $6.1 \quad(5.67)$ & 5 & $\begin{array}{ll}5.61 & (5.5) \\
\end{array}$ & 8 & $9.71 \quad(5.9)$ & 4 \\
\hline $\begin{array}{l}\text { Total of the five } \\
\text { states }\end{array}$ & $43.5(42.9)$ & & 44.9 (43.1) & & $55.3(43.1)$ & \\
\hline \multicolumn{7}{|l|}{ Expenditure } \\
\hline \multirow[t]{2}{*}{ State } & \multicolumn{2}{|c|}{$43^{\text {rd }}$ round $(1987-88)$} & \multicolumn{2}{|c|}{$50^{\text {th }}$ round (1993-94) } & \multicolumn{2}{|c|}{$55^{\text {th }}$ round $(1999-2000)$} \\
\hline & $\begin{array}{l}\text { Per cent of } \\
\text { national total of } \\
\text { expenditure-poor } \\
\text { (Per cent of } \\
\text { national } \\
\text { population) }\end{array}$ & $\begin{array}{l}\text { Rank in terms of } \\
\text { number deprived } \\
1987-88\end{array}$ & $\begin{array}{l}\text { Per cent of } \\
\text { national total of } \\
\text { expenditure-poor } \\
\text { (Per cent of } \\
\text { national } \\
\text { population) }\end{array}$ & $\begin{array}{l}\text { Rank in terms of } \\
\text { number deprived } \\
1993-94\end{array}$ & $\begin{array}{l}\text { Per cent of } \\
\text { national total of } \\
\text { expenditure-poor } \\
\text { (Per cent of } \\
\text { national } \\
\text { population) }\end{array}$ & $\begin{array}{l}\text { Rank in terms of } \\
\text { number deprived } \\
1999-2000\end{array}$ \\
\hline UP & $14.99(12.81)$ & 1 & $15.28(13.1)$ & 2 & $15.2(13.4)$ & 2 \\
\hline Bihar & $13.25(9.63)$ & 2 & $17.35(10.1)$ & 1 & $18.51(10.5)$ & 1 \\
\hline MP & $11.23(7.83)$ & 3 & $11.36(7.83)$ & 3 & $13.46(7.4)$ & 3 \\
\hline Andhra Pradesh & $8.14(7.43)$ & 4 & $7.08(7.11)$ & 6 & $8.14(7.47)$ & 5 \\
\hline Maharashtra & $7.86(7.03)$ & 5 & $8.16(6.5)$ & 5 & $6.02(5.91)$ & 7 \\
\hline $\begin{array}{l}\text { Total of the five } \\
\text { states }\end{array}$ & $55.47(44.73)$ & & $59.23(44.64)$ & & 61.35 (44.66) & \\
\hline
\end{tabular}

Source: Authors' calculations based on National Sample Survey Data.

The lower panel of Table 5 reports results from an analogous analysis in terms of the number of people falling below the expenditure poverty line. Thus in 1987-1988 UP had the largest number of expenditure poor in the Indian rural sector - with 14.99 per cent of the national number. 
The single most important conclusions to be drawn from this table is that the shares of the chosen five states (in each case) in the number of deprived increased steadily over time even though their share of national rural population remained almost constant. In 1987-88 UP, Bihar, MP, Maharashtra and Tamilnadu together had 43.5 per cent of the total nutritionally deprived in India's rural sector. This increased to 44.9 per cent in 1993-94 and 55.3 per cent in 1999-2000. The combined shares of these states in national rural population was, however, almost steady at 43 per cent over this period.

The combined share of UP, Bihar, MP, Andhra Pradesh and Maharashtra in the national expenditure-poor figure was 55.47 per cent in 1987-88. This increased to 59.23 per cent in 1993-94 and to 61.35 per cent in 1999-2000. However, the combined share of these five states in national rural population was almost steady at slightly above 44.6 per cent.

The increasing concentration of deprivation has created a situation in which the poor are ill placed to take advantage of new opportunities created by economic reforms just as they may suffer less from the loss of old opportunities in sectors that were artificially protected prior to reforms. Thus the poor do not have much stake in the success of the economic reforms program. In a democratic country such as India, this means that political parties espousing pro-reform policies may not necessarily win elections. This has emerged as a significant constraint on rapid economic growth in India.

\section{(ii) Rising Unemployment}

An additional emerging constraint on rapid economic growth in India is the inability - at least so far - of the reforms to generate a sufficient number of jobs. India has long had problems with unemployment and underemployment. However, economic growth in the pre-reform period did impact on unemployment by raising the demand for labour. The employment elasticity of output growth was high. But, one of the characteristics of post-reform economic growth in India has been the relatively sluggish growth of employment even in the face of buoyant output growth.

Unemployment statistics in India have been classified into three separate categories: (i) usual status (us), (ii) current weekly status (cws) and (iii) current daily status (cds). 'Usual’ status indicates the extent of unemployment 'for a relatively longer period during the reference period of 365 days' and indicates the magnitude of chronic unemployment. However, some of 
those who are unemployed by this criterion might be working in a subsidiary capacity. When the unemployment rate excludes those employed in subsidiary capacity, the corresponding figures are reported in column 'us adjusted'. Weekly status indicates the number unemployed (per thousand) during the average week of the survey year. It includes those who are chronically unemployed as well as those who are intermittently unemployed among the usually employed category due to seasonal fluctuations in the labor market. Lastly, the daily status gives the same information for an average day during the survey year. The S.P. Gupta committee has recommended the use of Current Daily Status (CDS) for measuring employment, as this measure of employment is net of the varying degrees of unemployment experienced by those who are otherwise classified as employed on usual status basis. Hence we present results using this criterion in this chapter. Table 6 provides details on employment and unemployment in India in recent times.

Table 6: Employment and Unemployment on Current Daily Status (CDS) Basis

\begin{tabular}{|c|c|c|c|c|c|}
\hline & \multicolumn{3}{|c|}{ (Million) } & \multicolumn{2}{|c|}{ Growth per annum (\%) } \\
\hline & 1983 & 1993-94 & $1999-00$ & 1983 to $1993-94$ & $\begin{array}{l}1993-94 \text { to } \\
1999-2000\end{array}$ \\
\hline & \multicolumn{5}{|c|}{ All India } \\
\hline Population & 718.20 & 894.01 & 1003.97 & 2.0 & 1.95 \\
\hline Labour Force & 261.33 & 335.97 & 363.33 & 2.43 & 1.31 \\
\hline Workforce & 239.57 & 315.84 & 336.75 & 2.70 & 1.07 \\
\hline Unemployment Rate (\%) & 8.30 & 5.99 & 7.32 & & \\
\hline \multirow[t]{2}{*}{ Number unemployed } & 21.76 & 20.13 & 26.58 & -0.08 & 4.74 \\
\hline & \multicolumn{5}{|c|}{ Rural } \\
\hline Population & 546.61 & 658.83 & 727.50 & 1.79 & 1.67 \\
\hline Labour Force & 204.18 & 255.38 & 270.39 & 2.15 & 0.96 \\
\hline Workforce & 187.92 & 241.04 & 250.89 & 2.40 & 0.67 \\
\hline Unemployment Rate (\%) & 7.96 & 5.61 & 7.21 & & \\
\hline \multirow[t]{2}{*}{ Number unemployed } & 16.26 & 14.34 & 19.50 & -1.19 & 5.26 \\
\hline & \multicolumn{5}{|c|}{ Urban } \\
\hline Population & 171.59 & 234.98 & 276.47 & 3.04 & 2.74 \\
\hline Labour Force & 57.15 & 80.60 & 92.95 & 3.33 & 2.40 \\
\hline Workforce & 51.64 & 74.80 & 85.84 & 3.59 & 2.32 \\
\hline Unemployment Rate (\%) & 9.64 & 7.19 & 7.65 & & \\
\hline Number unemployed & 5.51 & 5.80 & 7.11 & 0.49 & 3.45 \\
\hline
\end{tabular}

Source: Economic Survey, Government of India, 2002-03

The data in Table 6 originate from labour market studies of the National Sample Survey. There appears to have been a sharp decline in the rate of employment growth in the 1990s. This decline has been associated with a comparatively higher rate of growth of GDP, 
indicating a decline in the labour intensity of production. Further, the data reveal that the decline in the rate of growth of employment was associated with a sharp decline in the rate of growth of the labour force. Both the absolute number of unemployed as well as the incidence of unemployment (expressed in terms of unemployed as a percentage of the labour force) increased during this period.

To discover the underpinnings of the drop in the growth of employment we examine the sectoral composition of employment growth. This is reported in Table 7.

Table 7: Sectoral Employment Growth (CDS Basis)

\begin{tabular}{|c|c|c|c|c|c|c|c|c|}
\hline \multirow[b]{2}{*}{ Sector } & \multicolumn{4}{|c|}{ Employment (in million) } & \multicolumn{4}{|c|}{ Annual growth (per cent) } \\
\hline & 1983 & $1987-88$ & 1993-94 & $1999-2000$ & $\begin{array}{l}1983 \text { to } \\
1987-88\end{array}$ & $\begin{array}{c}1987-88 \text { to } \\
1993-94\end{array}$ & $\begin{array}{c}1983- \\
1993-94\end{array}$ & $\begin{array}{l}1993-94 \text { to } \\
1999-2000 \\
\end{array}$ \\
\hline Agriculture & 151.35 & 163.82 & 190.72 & 190.94 & 1.77 & 2.57 & 2.23 & 0.02 \\
\hline \multicolumn{9}{|l|}{ Industry, of which } \\
\hline Mining and quarrying & 1.74 & 2.40 & 2.54 & 2.26 & 7.35 & 1.00 & 3.68 & -1.91 \\
\hline Manufacturing & 27.69 & 32.53 & 35.00 & 40.79 & 3.64 & 1.23 & 2.26 & 2.58 \\
\hline $\begin{array}{l}\text { Electricity, gas and water } \\
\text { supply }\end{array}$ & 0.83 & 0.94 & 1.43 & 1.15 & 2.87 & 7.19 & 5.31 & -3.55 \\
\hline Construction & 7.17 & 11.98 & 11.02 & 14.95 & 12.08 & -1.38 & 4.18 & 5.21 \\
\hline \multicolumn{9}{|l|}{ Services, of which } \\
\hline $\begin{array}{l}\text { Trade, hotels and } \\
\text { restaurants }\end{array}$ & 18.17 & 22.53 & 26.88 & 37.54 & 4.89 & 2.99 & 3.80 & 5.72 \\
\hline $\begin{array}{l}\text { Transport, storage and } \\
\text { communication }\end{array}$ & 6.99 & 8.05 & 9.88 & 13.65 & 3.21 & 3.46 & 3.35 & 5.53 \\
\hline $\begin{array}{l}\text { Financial, insurance, real } \\
\text { estate and business } \\
\text { services }\end{array}$ & 2.10 & 2.59 & 3.37 & 4.62 & 4.72 & 4.50 & 4.60 & 5.40 \\
\hline $\begin{array}{l}\text { Community, social and } \\
\text { personal services }\end{array}$ & 23.52 & 27.55 & 34.98 & 30.84 & 3.57 & 4.06 & 3.85 & -2.08 \\
\hline All sectors & 239.57 & 272.39 & 315.84 & 336.75 & 2.89 & 2.50 & 2.67 & 1.07 \\
\hline
\end{tabular}

The decline in the overall growth rate of employment in 1994-2000 was largely attributable to two factors: a near stagnation of employment in agriculture and a slowdown in public sector employment. The share of agriculture in total employment dropped substantially from 60 per cent in 1993-94 to 57 percent in 1999-2000. On the other hand, employment growth in all the sub-sectors within services (except community, social and personal services having negative growth rates) exceeded 5 per cent per annum. As has been the trend in the past, the share of casual labour in total employment has gone up. 
Only a small percentage (8 to 9 percent) of the total workforce of the country is employed in the organized sector. While employment growth in the private organized sector improved significantly in the 1990s, the growth in employment in the public sector was negligible. Since the public sector accounts for more than two thirds of the total organized sector employment, there was a substantial slow down of the overall growth in organized sector employment.

The Ninth Five Year Plan of the Government of India projected a decline in the population growth rate to 1.59 per cent per annum by the end of the Ninth Plan, from over 2 per cent in the previous three decades. However, it expected the growth rate of the labour force to reach a peak level of 2.54 per cent per annum over this period; the highest it has ever been and is ever likely to attain. This is because of the change in age structure, with the highest growth occurring in the 15-19 years age group in the Ninth Plan period.

The Ninth Plan expected an additional 53 millions to join the labour force on the "usual status" concept basis. It assumed a GDP growth rate of an average of 7 percent during the Plan period. This, together with greater emphasis on agriculture, was expected to help create 54 million work opportunities over the period. This would lead to a reduction in the open unemployment rate from 1.9 per cent in 1996-97 to 1.47 per cent in the Plan's terminal year, that is, by about a million persons - from 7.5 million to 6.63 million.

Thus the Plan emphasized the view that a GDP growth rate of about 7 percent would be required to absorb the new additions to the labour force. If the economy could grow at around 8 per cent per annum during the Plan period, the incidence of open unemployment could be brought down by two million persons, thus attaining near full employment by the end of the Plan period, according to the Plan. It is quite clear now that target of India's Ninth Five-Year Plan to create 54 million new jobs during the Plan period (1997-2002) has not been fulfilled. The economy grew at a rate slower than 7 percent and agricultural investment was sluggish. In addition, there was at least one year of poor agricultural growth. These factors combined to ensure that employment did not grow as anticipated in the Ninth Plan.

In addition to open unemployment there also exists India's persistent problem of underemployment. Underemployment in various segments of the labour force is quite high. The estimates of the $50^{\text {th }}$ Round of the NSS indicate that although open unemployment was only 
2 per cent in 1993-94 on US basis, the incidence of under-employment and unemployment taken together was as much as 10 per cent that year. This occurred despite the fact that the incidence of underemployment was reduced substantially in the decade ending 1993-94.

The higher unemployment creates a political climate in which policy measures such as increased liberalization of international trade become increasingly difficult to take since such policies may be construed to involve short-term increases in unemployment or, at the least, increase the perceived uncertainty of tenure of employment. In fact since liberalization policies might entail greater vulnerability to external risk, there might well be pressures for governments to increase employment in the public sector (Rodrik, 1998). This might well bloat up the size of an inefficient public sector and reduce the effectiveness of any economic reforms program.

\section{(iii) High Fiscal Deficit}

India's fiscal deficit woes have been well documented (see, for instance, Jha, Chand and Sharma (2003)). The combined fiscal deficit of the central and state governments has been hovering near 10 percent of GDP for quite some time now. Some details are provided in Table 8:

Table 8: Combined Receipts and Disbursements of the Central and State Governments (percent of GDP)

\begin{tabular}{|c|c|c|c|c|c|c|c|}
\hline & $1990-91$ & $1997-98$ & 1998-99 & $1999-00$ & $2000-01$ & $\begin{array}{l}\text { 2001-02 } \\
\text { (R.E). }\end{array}$ & $\begin{array}{c}2002-03 \\
\text { (B.E.) }\end{array}$ \\
\hline Total Receipts $(A+B)$ & 26.8 & 25.9 & 26.4 & 28.0 & 28.4 & 29.2 & 30.1 \\
\hline A. Revenue Receipts $(1+2)$ & 18.6 & 17.8 & 16.5 & 17.7 & 18.0 & 18.5 & 20.0 \\
\hline 1. Tax Receipts & 15.4 & 14.3 & 13.4 & 14.2 & 14.5 & 14.4 & 15.8 \\
\hline 2. Non-tax receipts, of which & 3.2 & 3.5 & 3.1 & 3.6 & 3.5 & 4.1 & 4.2 \\
\hline Interest receipts & 4.4 & 1.0 & 0.9 & 0.9 & 0.8 & 0.8 & 1.0 \\
\hline B. Capital Receipts, of which & 8.2 & 8.1 & 9.9 & 10.3 & 10.4 & 10.7 & 10.0 \\
\hline a) Disinvestment proceeds & 0.0 & 0.1 & 0.4 & 0.1 & 0.1 & 0.2 & 0.5 \\
\hline $\begin{array}{l}\text { b) Recovery of loans and } \\
\text { advances }\end{array}$ & 0.8 & 0.5 & 0.4 & 0.3 & 0.5 & 0.6 & 0.3 \\
\hline Total disbursements $(a+b+c)$ & 28.8 & 25.8 & 26.6 & 28.2 & 28.3 & 29.5 & 30.3 \\
\hline a) Revenue & 22.8 & 21.9 & 22.9 & 24.0 & 24.6 & 25.2 & 25.9 \\
\hline b)Capital & 3.9 & 2.8 & 2.6 & 3.1 & 2.9 & 3.4 & 3.6 \\
\hline c) Loans and advances & 2.1 & 1.1 & 1.0 & 1.1 & 0.8 & 0.9 & 0.8 \\
\hline Revenue deficit & 4.2 & 4.1 & 6.4 & 6.3 & 6.6 & 6.6 & 5.9 \\
\hline Gross fiscal deficit & 9.4 & 7.3 & 9.0 & 9.5 & 9.5 & 10.0 & 9.3 \\
\hline
\end{tabular}

N.B. B.E. = budget estimate, $\mathrm{R} . \mathrm{E} .=$ revised estimate

Source: Economic Survey, Government of India, 2002-03. 
As a result the public debt of India has been climbing steadily and is currently reported at about 85 percent of GDP. There has been a change in the composition of this debt, however, with the share of external debt falling and that of internal debt rising.

This persistently high fiscal deficit has had deleterious effects. It has reduced the amount of resources available for investment by lowering public saving. The saving rate in India at 23.1 percent of GDP is lower than the levels needed to sustain growth rates of 8 percent and above for long. In addition, public dissaving because of the high fiscal deficit is reducing the resources available for investment (Saggar, 2003). Since 1998-99 the public sector has been dissaving continuously. Furthermore, some of the savings-investment gap spills over onto the external balance. In addition, persistent pre-occupation with controlling the fiscal deficit reduces the flexibility to conduct countercyclical fiscal policy.

Budgetary deficits - directly measured - are only part of the fiscal burden of the state in India. It is well-known that contingent liabilities of the government are very large. In the past the government has had to bail out insolvent banks and other financial institutions (the latest being the Unit Trust of India) at severe cost (Sharma, 2004).

\section{(iv) Problems of Infrastructure}

India's record in providing high quality, reliable and reasonably priced infrastructural services to its households and businesses has been inadequate. The World Economic Forum's 1998 Global Competitiveness Report ranked India last among 53 countries on the quality of overall infrastructure services. ${ }^{8}$ Indian households and businesses still receive infrastructure services largely through the public sector — often through government departmental undertakings. There is sufficient evidence to suggest that this state of affairs will continue for some time. Even though the potential of the private sector to meet India's pressing infrastructure needs is largely untapped, and hence can be expanded considerably, there will continue to be a major role for the public sector in providing infrastructural services, particularly in the less developed regions/states of India. India’s infrastructure requirements have been put by one estimate at US\$215 billion in the 2001 to 2006 period. ${ }^{9}$

However, before such investment can take place, the paucity of infrastructural facilities hampers rapid economic growth. Jha and Thapa (2003) document that states with poor

\footnotetext{
${ }^{8}$ This ranking is cited in World Bank (2000).

${ }^{9}$ Estimates by the Expert Group on the Commercialization of Infrastructure Projects reported in NCAER (1996).
} 
infrastructure have poor records of poverty reduction. Further, there is clear linkage between agricultural productivity and agricultural infrastructure. Jha and Thapa (2003) also document the links between poor pricing of electricity and aggravated distortions in its usage as well as huge losses in transmission and distribution.

The upshot of these arguments is that there are important constraints to rapid economic growth in India. Whereas high levels of the fiscal deficit and public debt reduce resources available for investment, poor infrastructure facilities reinforce the tendency toward increasing concentration of poverty. The fact that some of the poorest regions in the country have poor economic reform and governance records as well as some of the highest population densities and thus have high representation in Parliament indicates that reform measures that do not appear to be beneficial in the short run have little political support. The fact that unemployment has actually increased during the period 1993-94 to 1999-00 is further indication of the lack of popular support for rapid liberalization and reform.

\section{Prospects for alleviating the constraints on rapid economic growth}

That rapid economic liberalization of the form that took place in China beginning in the late 1970s is difficult to achieve in India is now clear. In a democratic society tolerance for rapidly increasing inequality and slow realization of gains of liberalization for the poor is low. For instance, India will not be able to countenance the vast regional inequality that has emerged in China between the coastal areas and the interior. Hence, relieving the constraints on building consensus for rapid liberalization is an essential part of the strategy to sustain rapid economic growth in India.

How likely is this? Although there exists room for reorienting subsidies it is difficult to see how their total magnitude can be reduced significantly. Some expenditures are highly inflexible and three such items (interest payments, defence expenditure and subsidies) make up almost 100 percent of tax revenues. India's expenditure/GDP ratio is not much out of line for developing countries and is substantially below that of OECD countries.

However, there is much to be gained from tax reform and substantial opportunity exists for raising the tax/GDP ratio. This ratio has been stagnant for some time now and is substantially below that of OECD and even some developing countries. Jha, Chand and Sharma (2003) discuss the contours of a tax reform program to raise the tax/GDP ratio. This involves expanding the tax net by removing exemptions and taxing services as well as 
agricultural income, consolidating and rationalizing indirect taxes into a value added tax and improving tax administration.

Such tax reform and lowering the fiscal deficit becomes even more necessary because of the extent of contingent liabilities of the government. These include but are not confined to the non-performing assets of banks.

Taking efforts to increase the employment elasticity of income growth is another important challenge facing Indian policymakers. Rapid rise in agricultural employment must await substantial investment - particularly in agricultural infrastructure. Employment growth in the services sector has been impressive but the capacity of this sector to absorb labour is limited. For purposes of employment expansion India will have to rediscover its latent comparative advantage in low value added manufacturing. This has been the area of most rapid growth in China and several Southeast Asian countries. India did not enter this club and imposed high tariffs on these products while at the same time producing these product domestically in “small scale industries”, many of which were granted reservations for producing specific goods. The result has been high cost production which is non-competitive both in the domestic and international markets.

A more enlightened policy would be to remove the reservations for the small scale industrial sectors as well as reducing tariffs. Labour market regulations can be made more flexible. After decades of high GDP growth China and Southeast Asia have moved up the value chain in manufacturing production and India could well occupy the vacated low value added manufacturing space. Indeed India could become one of the most important production centres in these areas. This also has the potential to create large increases in employment.

Improvements in policy towards infrastructure have been suggested in a number of documents (see for example, India Infrastructure Report 2002, World Bank 2004). India is slowly moving in the direction of introducing competitive markets in infrastructure, with private sector production under modern regulatory structures. As a consequence some progress has been made in the areas of telecom, roads, ports, electricity and aviation. But much remains to be done. For example, in the area of electricity, the big change is the Electricity Act, which has mooted the idea of a pro-competitive framework whereby producers and consumers of electricity can interact in an unfettered market. However, after the 2004 Parliamentary elections the new government has already announced that the 
implementation of the Electricity Act would be delayed by a year. In the meantime, a number of states have reverted to the practice of providing free electricity to farmers. Thus progress on this front has been slow and there have been some retrograde steps as well.

Furthermore, political expediency has imposed several serious burdens on the Indian railways. An immediate reason for this is the paucity of funds. Until about 1995 Indian Railways had been earning a surplus - now they have been accumulating huge and growing deficits. This has resulted in serious shortage of funds for modernization of the rail networks. New trains are introduced every year but there are very limited funds for even maintenance of tracks. The increasing financial burden on the railways is the result of several factors. First, there is gross cross-subsidization of lower class travel by upper class travel. Organizational structures have progressively been distorted with duplication of services. The partial privatisation of railway services that had been advocated has now been all but abandoned. Pay revisions consequent upon the Fifth Pay Commission's Report the salary bill of the Railways has gone up inordinately high: without corresponding growth in productivity, staff costs of Indian Railways account for around 50 per cent of the organisation's gross traffic receipts. The pension bill is also rising fast. While the pension pay out was 6.3 per cent of gross revenues in 1986, it is now almost 15 per cent and is set to rise even further. Hence the financial and operational condition of the Indian Railways does not show any sign of recovering soon.

The one area in which considerable progress can be expected is telecom. Mobile telephone and associated technology has grown rapidly in India. India has in excess of 40 million mobile phones with a rate of growth of 2 million phones a month. Internet access has improved considerably and there are plans to bridge the rural-urban divide in internet connectivity by rapid expansion of services in rural areas. But the recent decision to abandon the privatisation of MTNL (a government owned phone company serving Delhi and Mumbai) is a retrograde step.

Some progress has also been achieved in the areas of roads. There is a substantial project to build new highways - including the so-called "golden quadrilateral” to connect the four major cities of New Delhi, Mumbai, Kolkata and Chennai with six lane expressways and supplementary feeder routes. Such programs will enable more rapid transport of goods and services between vast distances and enable firms separated by such distances to trade with each other directly. 
The functioning of ports has also recorded some improvements - partly as a result of contracting out the operations of ports to international firms with specialised expertise on this subject. According to Kelkar (2004) the turnaround time at ports dropped by half, from 7.5 days in 1996-97 to 3.5 days in 2001-02. Airport privatisation has however suffered a setback after the 2004 elections as has the whole process of privatisation, per se.

Thus the prospects for effective alleviation of the constraints facing higher economic growth are mixed. However, just in order to ensure adequate employment opportunities, India needs real GDP growth of about 7 percent per annum. It remains to be seen whether a forward looking economic reforms program able to work around some of these constraints and ensure high and stable growth can be put in place.

\section{Conclusions}

After two decades of economic reforms the Indian economy is at a crossroads. The reforms program has yielded considerable returns in the form of higher and more stable growth as well as considerable modernization of the economy. After more than two decades of impressive economic growth and some important reforms as well as deregulation, the Indian economy is at the threshold of even higher growth.

However, unforeseen and stubborn challenges have been thrown up especially in the areas of the high fiscal deficit and financial sector weakness, increasing regional and personal inequality, low elasticity of employment with respect to growth and inadequate infrastructure. Several of these, e.g., inadequate decline in poverty are such that they can be addressed best by high and sustained economic growth. However, these might act as short-term constraints on economic reforms especially when they play themselves out through the democratic process. This is an important challenge for policymaking in India.

The Indian economy is currently showing considerable promise in terms of growth performance. However, success in attaining high and sustained rates of economic growth is not automatically guaranteed. 


\section{References:}

Government of India, Finance Commission (1994) Report of the Tenth Finance Commission, New Delhi.

India Infrastructure Report (2002), 3i Network, New Delhi: Oxford University Press.

Jha, R. (2001) Economic Reforms, Economic Growth and Anti-Poverty Strategy in India, Country Strategic Opportunities Paper, International Fund for Agricultural Development, Rome, 2001

Jha, R. and A. Sharma (2003) "The Spatial Distribution of Rural Poverty in the last three Quinquennial Rounds of the NSS, Economic and Political Weekly, vol. 38, no.47, pp. 4985-4993.

Jha, R., Chand, S. and A. Sharma (2003) “The Fiscal Constraint on India’s Economic Growth” in R. Jha (ed.) Indian Economic Reforms, Basingstoke, Houndmills, Palgrave Macmillan.

Jha, R. and P. Thapa (2003) “India's Infrastructure Sector” in R. Jha (ed.) Indian Economic Reforms, Basingstoke, Houndmills, Palgrave Macmillan.

Jha, R. (2004) "Reducing Poverty and Inequality in India: Has Liberalization Helped?” in Cornia, G.A. (ed.) Inequality, Growth and Poverty in an ear of Liberalization" Oxford, U.K. and New York: Oxford University Press.

Kelkar, V. (2004) "India: On the Growth Turnpike” 2004 Narayanan Oration, Australia South Asia Research Centre, Australian National University.

National Council of Applied Economic Research (NCAER) (1996) The India Infrastructure Report, Expert Group on the Commercialization of Infrastructure Projects, New Delhi.

Reserve Bank of India (2004) "Macroeconomic and Monetary Developments in 2003-04", Annual Policy Statement for 2004-05.

Rodrik, D. (1998) “Why do More Open Economies have Larger Governments?” Journal of Political Economy, 106(6), pp.997-1032.

Rodrik, D. and A. Subramanian (2004) “From 'Hindu Growth' to Productivity Surge: The Mystery of the Indian Growth Transition” International Monetary Fund Discussion Paper, WP/04/77.

Saggar, M. (2003) “ A Perspective on Saving, Investment and Macroeconomic Policies in India” in R. Jha (ed.) Indian Economic Reforms, Basingstoke, Houndmills, Palgrave Macmillan.

Sharma, A. (2004) Fiscal Deficits, Banking Crisis and Adjustment in a semi-open Economy, unpublished Ph.D. dissertation, Australian National University.

Thirlwell, M. (2004) “India- the next economic giant” Lowy Institute, Sydney.

World Bank (2000) India: Country Framework Report for the Private Participation In Infrastructure, World Bank/Public-Private Infrastructure Facility, Washington, D.C. 